\title{
Full-Length cDNA Cloning, Molecular Characterization and Differential Expression Analysis of Lysophospholipase I from Ovis aries
}

\author{
Nan-Nan Liu ${ }^{1,+}{ }^{\dagger}$, Zeng-Shan Liu ${ }^{1,+}$, Pan Hu ${ }^{1,+}$, Ying Zhang ${ }^{1,+}$, Shi-Ying Lu ${ }^{1}$, Yan-Song Li ${ }^{1}$, \\ Yong-Jie Yang ${ }^{2}$, Dong-Song Zhang ${ }^{3}$, Yu Zhou ${ }^{1}$ and Hong-Lin Ren ${ }^{1, *}$ \\ 1 Key Laboratory of Zoonosis Research, Ministry of Education/Institute of Zoonosis/College of \\ Veterinary Medicine, College of Animal Sciences, Jilin University, Xi An Da Lu 5333, \\ Changchun 130062, China; liunannan112117@163.com (N.-N.L.); zsliu1959@163.com (Z.-S.L.); \\ hupan84@163.com (P.H.); zhangying201604@163.com (Y.Z.); lushiying1129@163.com (S.-Y.L.); \\ 1_ys92305@163.com (Y.-S.L.); zhouyu69@sina.com (Y.Z.) \\ 2 Department of Food Science, College of Agriculture, Yanbian University, Yanji 133002, China; \\ yjyang@ybu.edu.cn \\ 3 Animal Husbandry and Veterinary Unit of Xiangyang Town, Liuhe 135305, China; \\ zhangdongsong2016@163.com \\ * Correspondence: renhl@jlu.edu.cn; Tel.: +86-431-8783-5735 \\ $+\quad$ These authors contributed equally to this work.
}

Academic Editors: Mateus Webba da Silva and Ritva Tikkanen

Received: 3 May 2016; Accepted: 19 July 2016; Published: 28 July 2016

\begin{abstract}
Lysophospholipase I (LYPLA1) is an important protein with multiple functions. In this study, the full-length cDNA of the LYPLA1 gene from Ovis aries (OaLypla1) was cloned using primers and rapid amplification of cDNA ends (RACE) technology. The full-length OaLypla1 was $2457 \mathrm{bp}$ with a $5^{\prime}$-untranslated region (UTR) of $24 \mathrm{bp}$, a 3'-UTR of $1740 \mathrm{bp}$ with a poly (A) tail, and an open reading frame (ORF) of $693 \mathrm{bp}$ encoding a protein of 230 amino acid residues with a predicted molecular weight of 24,625.78 Da. Phylogenetic analysis showed that the OaLypla1 protein shared a high amino acid identity with LYPLA1 of Bos taurus. The recombinant OaLypla1 protein was expressed and purified, and its phospholipase activity was identified. Monoclonal antibodies (mAb) against OaLypla1 that bound native OaLypla1 were generated. Real-time PCR analysis revealed that OaLypla1 was constitutively expressed in the liver, spleen, lung, kidney, and white blood cells of sheep, with the highest level in the kidney. Additionally, the mRNA levels of OaLypla1 in the buffy coats of sheep challenged with virulent or avirulent Brucella strains were down-regulated compared to untreated sheep. The results suggest that OaLypla1 may have an important physiological role in the host response to bacteria. The function of OaLypla1 in the host response to bacterial infection requires further study in the future.
\end{abstract}

Keywords: Lysophospholipase I; Ovis aries; Brucella; tissue distribution; differential expression

\section{Introduction}

Lysophospholipase I (LYPLA1), also known as acyl-protein thioesterase 1 (APT1), is a widely distributed enzyme with phospholipase A2 [1], lysophospholipase [1,2] and acyl-protein thioesterase [3-5] activity. Phospholipids are important components in cellular membranes and are involved in signal transduction, mediator production and eicosanoid formation in both normal and disease states [6]. Lysophospholipids (LPLs) are important molecules in phospholipid metabolism and have received much attention as they are critical for cell survival and function [6-8]. LPLs are bioactive second messengers that modulate gene expression and are involved in multiple processes, such as 
stimulation of growth, phagocytosis of macrophages [6,9-12], activation of T lymphocytes [13,14], activation of many immune-related proteins [15], and promotion of anti-tumor and bactericidal activities [6]. LPLs are strictly regulated because increased levels of lysophospholipids are associated with many diseases [6,16]. The lysophospholipases (LYPLAs) are considered to be safeguards to ensure that normal levels lysophospholipids are maintained [6]. Multiple enzymes display LYPLA activity, and LYPLA1 belongs to the family of LYPLAs $[4,16]$.

Palmitoylation involves the attachment of a 16-carbon fatty acid palmitate via a thioester bond to specific cysteine residues of target proteins and is an important post-translational modification that is critical for protein localization and function [5]. In contrast to other lipid modifications, such as isoprenylation and myristoylation, palmitoylation is a unique reversible post-translational modification [17] that allows proteins to rapidly shuttle between intracellular membrane compartments $[18,19]$ and can be dynamically regulated by specific extracellular stimuli [18]. This modification is important for regulating protein subcellular localization, stability, trafficking, translocation to lipid rafts, aggregation, and interaction with effectors and other protein functions [17]. Recent studies have shown that palmitoylation is involved in endocytosis, reproduction, cell growth, fat and sugar homeostasis and signal transduction at the synapse [18]. Palmitoylation/depalmitoylation cycles are potential novel regulatory networks [20]. The multiple functions of palmitoylation suggest that it should be studied in detail. Palmitoylation is catalyzed by palmitoylation acyltransferases (PATs) while only a few enzymes catalyze depalmitoylation reactions $[5,21]$.

LYPLA1 was identified as an acyl-protein thioesterase (APT), which is a depalmitoylation enzyme, in addition to palmitoyl protein thioesterases (PPT) [3], and can catalyze the removal of mislocalized palmitoylated proteins from endomembranes by depalmitoylation [21-23]. The PPT is localized predominantly in the lysosome [24]. However, LYPLA1 is principally localized in the cytosol, while some is present in the plasma membrane, the nuclear membrane and the endoplasmic reticulum (ER) [21].

Brucellosis is a zoonotic disease found worldwide that is caused by Brucella, resulting in infectious abortion and fever [25]. Brucella infections are chronic, and the interaction between the host and the Brucella pathogen is continuous [26]. Virulent Brucella strains invade the macrophages through lipid rafts and then reside in an acidified compartment, which fuses with components of the early endosomal pathway $[27,28]$. The macrophages kill the majority of Brucella cells at an early stage of infection [28,29], and the remaining Brucella cells establish and maintain a persistent intracellular infection in host cells using many virulence factors and strategies. Brucella can also induce the loss of the robust antigen-processing capacity of professional phagocytes and prevent phagosome-lysosome fusion and programmed cell death of infected macrophages, favoring pathogen survival and replication [26,30-33]. The host transcriptional responses against infection by Brucella have been characterized in several studies $[28,34,35]$. It is crucial to understand the host response to Brucella. In our lab, a time course suppression subtractive hybridization (SSH) cDNA library of buffy coats from sheep (Ovis aries) infected with different virulent Brucella strains was constructed to analyze the modulation of transcriptional profiles of hosts exposed to Brucella infection, and the differentially transcribed genes were screened. Among these genes, a partial cDNA of LYPLA1 (OaLypla1) containing a full-length $3^{\prime}$-UTR was found to show differential expression in buffy coats from different virulent Brucella-infected sheep. As a result, the OaLypla1 gene was chosen as a target candidate gene to further study the response of the host to Brucella infection. LYPLA1 is a protease with diverse biological functions that catalyzes multiple different reactions. It was reported that LYPLA1 is down-regulated in macrophages after LPS stimulation [36]. However, the expression profiles of LYPLA1 gene of the host infected with bacteria and whether LYPLA1 takes part in the host immune response after the bacterial infection had not been investigated before. Thus, more information about the OaLypla1 is required to better understand the potential relationship between the expression profiles of OaLypla1 gene and bacteria infection. In this study, we identified the full-length cDNA sequence of a novel LYPLA1 gene from Ovis aries (O. aries) for the first time. The recombinant OaLypla1 protein 
was expressed and purified, and its phospholipase activity was assessed. The tissue distribution of OaLypla1 was determined, and differential expression profiles of OaLypla1 in the buffy coats of sheep following challenge with different virulent Brucella strains were observed. Furthermore, we generated a monoclonal antibody $(\mathrm{mAb})$ that reacts with the native OaLypla1. The results from this study may facilitate further study of the functions of OaLypla1 in the host response to infection with Brucella.

\section{Results}

\subsection{Characterization of OaLypla1 cDNA}

The full-length cDNA sequence of the OaLypla1 gene was obtained using $5^{\prime}$-RACE and deposited in GenBank (accession number KJ000742). The full-length OaLypla1 cDNA was 2457 bp with a $5^{\prime}$-UTR of $24 \mathrm{bp}$, an ORF of $693 \mathrm{bp}$ and a 3'-UTR of $1740 \mathrm{bp}$ with a poly (A) tail downstream of a polyadenylation signal (AATAAA). The full-length nucleotide sequence and the deduced amino acid sequence of OaLypla1 cDNA are shown in Figure 1.

\section{(20)KLS}

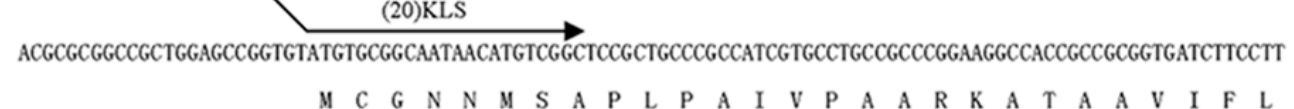
CATGGATTGGGAGACACAGGGCATGGATGGGCCGAAGCCTTTGCCGGGATCAGAAGCTCCCACATCAAATACATCTGCCCGCATGCGCCGGTTATGCCTGTAACA

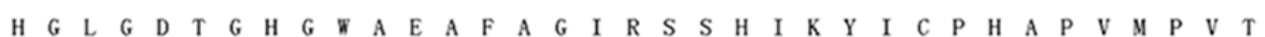
TTAAATATGAACATGGCCATGCCATCATGGTTTGACATTATTGGGCTTTCACCAGATTCACTGGAGGATGAAACTGGAATTAAACAGGCAGCAGAAAATGTAAAA

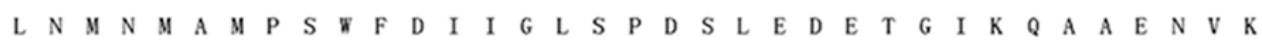
GCTTTGATAGATCAGGAGGTGAAGAACGGCATTCCTTCTAACAGAATTATTTTGGGAGGATTTTCTCAGGGAGGAGCTTTATCTCTGTACACGGCTCTGACCACA

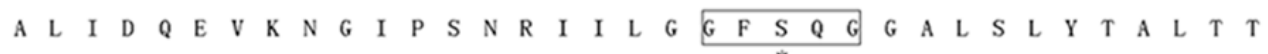
OaLypla1S CAGCAGAAGCTGGCCGGGGTCACCGCTCTCAGCTGCTGGCTGCCACTGCGGGCTTCGTTTCCACAGGGCCCTATTGGTGGCGTGAACAGAGACATTTCTATTCTT

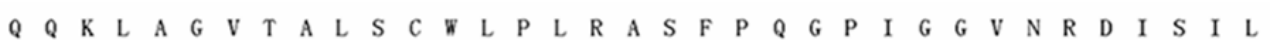

CAGTGCCACGGGGACCTGGATCCTCTAGTCCCCCTGATGTTTGGTTCTCTCACTGCTGAGAAGCTGAAGACATTGGTGAATCCAGCCAATGTGACCTTCAGAACC

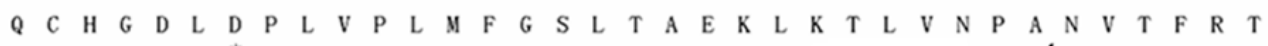
OaLypla1A (20)KLHisA TACGCAGGCATGATGCACAGTTCATGTCAACAGGAATGATGGACATCAAGCAGTTCATTGATAAGCTCCTACCTCCCATTGACTGACACCGCCAAGAGGCCTTG $\begin{array}{lllllllllllllllllllllllllllll}Y & A & G & M & M & H & S & S & C & Q & Q & E & M & M & D & I & K & Q & F & I & D & K & L & L & P & P & I & D & *\end{array}(20) K L W A$

TGTAGAAGTGCACACCAGCATCGTCCAGTGGAGCACACACTTCTTCCTGTGCCCGACCTTGAAACCTCTAATGTTTGCAGTGTTAAACGTTTTGCAAATATACA CCAATGACACAGACTAAATAAATCTCCTCGTGGGAAATGTATGATCTTTGACATTTCTCTATATGTATTTGTATATGATCCAGGATACACTAGTATTAAATAGA TGAAGCAGCCAGCTTCTTTCTCCCAAATGTAATTCAGCAAAATCATAAAATACTGCAGCCGGACCTTTTTTTACTAGATCACTTGAAATTACTAGTATGCTTAA TGAAAACTTGTTCAGGTGTAAATGAGGATTTAAGACATAAAGGTTTATACGTGCTGTGACTTAGGACTATGGTCATATCCCCAAATACATAGTCACCATGCAG TATCCATATTTTTATATATGTGTTCTTATATACTTAATGATTATAATATTAAGAATGAGGTGTTATTACATTATTTCTTATAAGAGGGATAATGCTTCTAAGTGT CCATAAAGAGTAATATTGCTCTCTAGAATTAATGGCCCTTTTATTTTGGGGACCAGGTTTTTCTTTGCTGAATATGATTTCTGTTCTATTTAATATTCTTTTTTC CTCTCTAGAAATATGTTCTTTCTTTTTATGCTTCATAACAGACCAAATATTGCCTCCTTGCCATAGACACTTGCAGTCAATATATGCTGTAATTTGACATTCTGA ATCACAGAAGAGGTGGAGTAAAAATGTATTGATACTTATAGAAAGAAACCTGACTTCCCTTCAGAGTTTGTACACTACTTCCTAAACTGGAGTTTAGTCCACATT TTGGACCTTCAGAGTTACTAGAATCTTCAGTGCAGGAAATGAAAATAATTCTGTGGTTGTATTTTCCTGTAATTAACTGAAAGAATAGTTAGTTCATATTCTAGT ATGTTCTGGAATATTTAAAGCTGATCTTAAAAACTGTAATCTCTAAGATGATTTGCTCTAAGGTGATTCTCCTCATAGCATAGAATTTACTTATTCTGCACGTTT GAAACCGACTGCTGTAGGAACTGAGCAATCATTTCAAAAATTTGCTTTATTCTTCTCTGTCAACAGACTCATTTAAAATTTTCACTGTAGTCAAATGATATTTT TAAGTTAGCTTTTGTGCAAATGTAAAAATAGCAATTATTTGATTTTAAATAATCAGATTTTTCAAACTATCGGTTAAAATTACTTGAAAATAAATTTATGGGTAA CAAAAGTTAGTCAGAACTCAATACATGTGGTGTAGTTACCACACAGTTTAATACATACCAAAAATGTACACTTGATATTTCTGAGTTGGTCGTTTTCTGCTGTA NGSP

TTCCAGCTGACTAGGACAGTGTTAGGATGGCATCTTCATAATGGGTGCTATTTGATGATGGAAGTGACTTGGTATGGACTACATAGAGCATGTGAATAATGAAG CCATATGTTTATGTCTGGATTCACAGTTTTTAAACAATCATTTACTAAGTCATTCTGCTTTACCTTGAAGAATATAAACTGTTGTTTCACTGACACAAATCAGCA GSP

AGATCTAACTTATGGCAAGAAATAGTCCATTGAAATACTGTGCTATAACGTGGGAAAATGTAAATCTTTTTCACGGTTTCTATCAATGTGAAATAAATTGAATT CTGACTTTGCTGTGAATAAAAAAAAAAAAAAAAAAAAAAA

Figure 1. The full-length cDNA and the corresponding amino acid sequence of OaLypla1. The polyadenylation signal sequence (AATAAA) is shown in bold and underlined. The lipase motif GXSXG is boxed, and the catalytic triad is marked by asterisks $\left({ }^{*}\right)$. The arrows represent the places and lengths of the primers $\left(5^{\prime}-3^{\prime}\right)$ used in this study. 
The predicted OaLypla1 protein consisted of 230 amino acid residues with a predicted molecular weight of 24,625.78 Da and a theoretical isoelectric point of 6.77. The deduced OaLypla1 protein contained a ${ }^{117}$ GFSQG $^{121}$ amino acid sequence corresponding to the GXSXG motif, which was located in an identical position to the amino acid sequence of the human LYPLA1 protein. A search using the BLASTn program in NCBI showed that the OaLypla1 cDNA had 96\% identity with the LYPLA1 cDNA from Bos taurus (GenBank accession number: BC105143). Using the BLASTP program, the deduced amino acid of $O$. aries OaLypla1 was shown to exhibit high homology with the LYPLA1 proteins of other species, such as Bos taurus (99\% identity), Pongo abelii (95\% identity), Homo sapiens (95\% identity), Macaca mulatta (94\% identity), Cricetulus griseus (93\% identity), Xenopus tropicalis ( $82 \%$ identity), and Dicentrarchus labrax (78\% identity).

Multiple sequence alignment analysis of OaLypla1 was conducted using the known LYPLA1 proteins from several vertebrates to determine the level of amino acid conservation. The results showed that highly conserved acids were observed in the entire protein sequence as shown in Figure 2. The deduced amino acid sequence of LYPLA1 from O. aries had the Ser ${ }^{119}$, Asp $^{174}$ and His ${ }^{208}$ triad that formed the catalytic site for LYPLA1 proteins from the mouse [37] and human [2]. All of these proteins shared the GXSXG motif sequence $\left({ }^{152} \mathrm{GFSQG}^{156}\right)$, which had a similar position and was found in the active site of serine proteases, esterases and lipases [6].
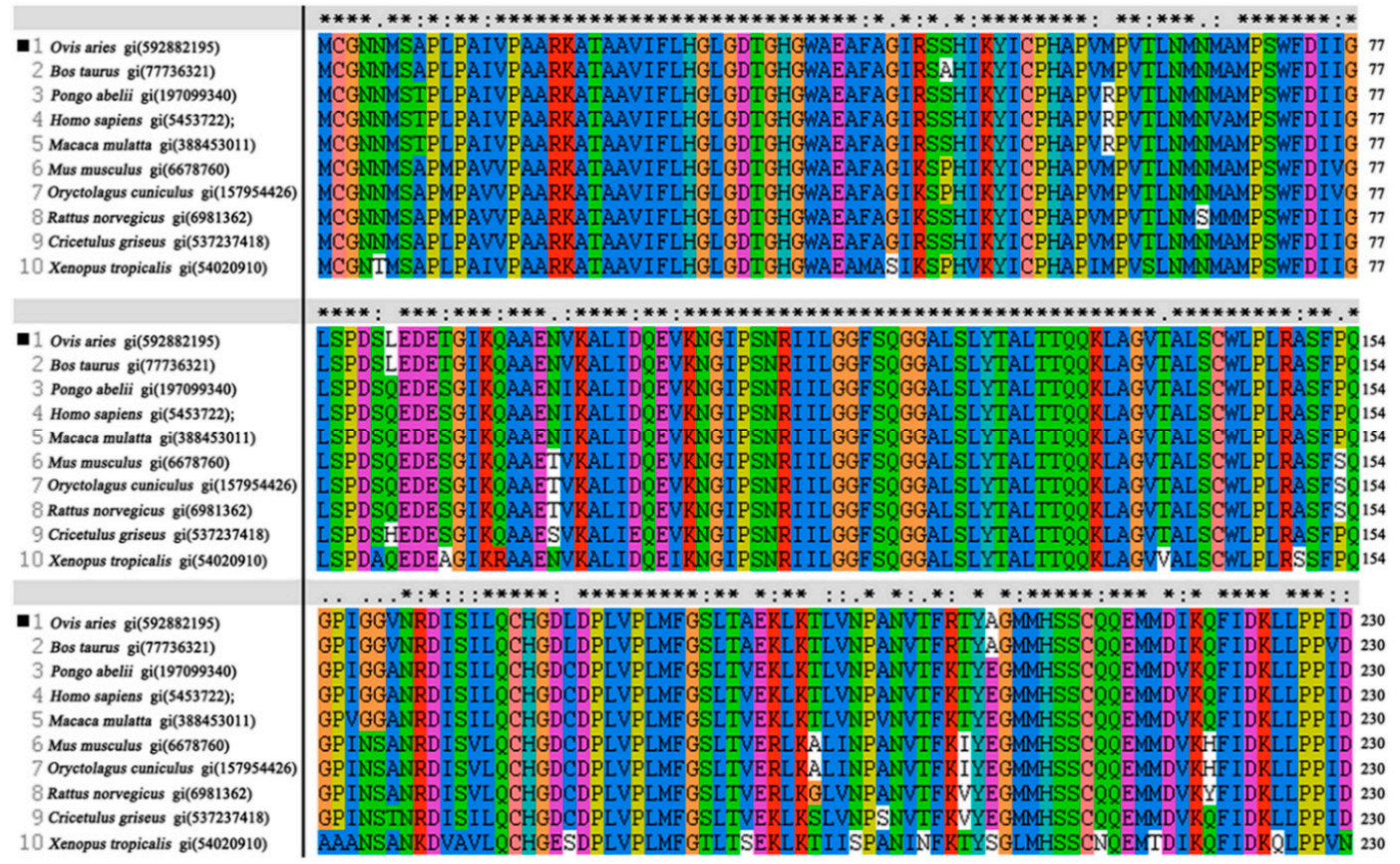

Figure 2. Multiple alignment analysis of the amino acid sequences of LYPLA1s from different vertebrates. The conserved amino acid residues of LYPLA1s are indicated by asterisks $\left(^{*}\right)$ above the column. Conserved substitutions are shown by colons (:), and dots (.) indicate semi-conserved amino acids. GenBank GI numbers of LYPLA1 protein sequences are given as follows: Ovis aries LYPLA1: gi (592882195); Bos taurus LYPLA1: gi (77736321); Cricetulus griseus LYPLA1: gi (537237418); Homo sapiens LYPLA1: gi (5453722); Macaca mulatta LYPLA1: gi(388453011); Mus musculus LYPLA1: gi (6678760); Oryctolagus cuniculus LYPLA1: gi (157954426); Pongo abelii LYPLA1: gi (197099340); Rattus norvegicus LYPLA1: gi (6981362); and Xenopus (Silurana) tropicalis LYPLA1: gi(54020910). The different colors are used to differ the proteinogenic 20 amino acids. Red: R and K; Brick red: G; Orange: C; Yellow: P; Green: N, S, T, and Q; Indigo: H and Y; Blue: M, A, L, I, V, F and W; Purple: D and E.

To determine the phylogenetic relationships of OaLypla1, the amino acid sequences of LYPLA1 proteins from different species were selected. The phylogenetic tree was constructed by the neighbor joining method and revealed that the deduced amino acid sequence of OaLypla1 clustered with the 
ruminant subgroup near LYPLA1 from Bos taurus (Figure 3), suggesting that the gene cloned from O. aries belongs to the LYPLA1 family.

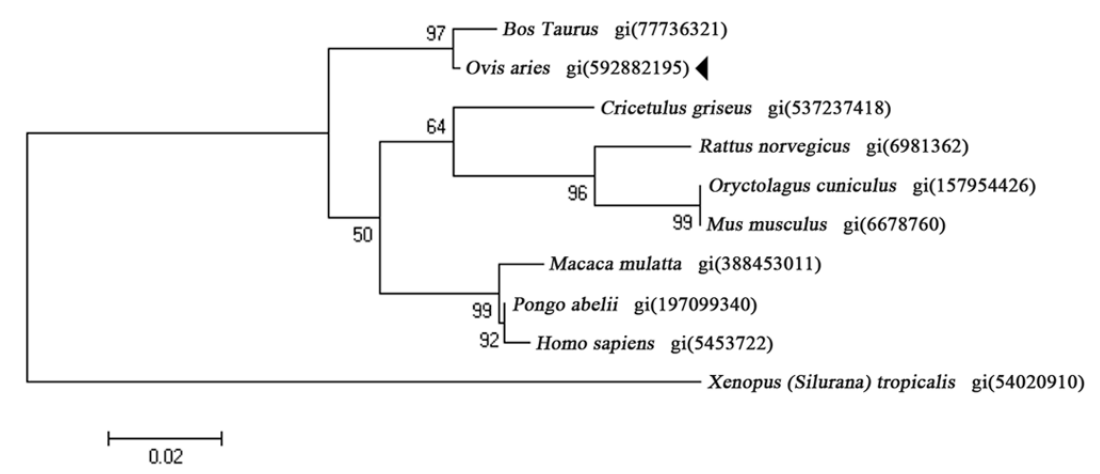

Figure 3. Phylogenetic relationship of LYPLA1 proteins from different species. The phylogenetic tree was constructed using MEGA 4.1 with the ClustalW algorithm. The number on the nodes indicates bootstrap values from 1000 replications.

\subsection{Protein Expression}

The coding sequence of OaLypla1 was cloned and inserted into the pET-30a vector. The recombinant proteins OaLypla1H (with a His $6_{6}$-tag) and OaLypla1W (with no tag) were over-expressed in E. coli BL21 (DE3). The results of SDS-PAGE analysis showed an approximately $25 \mathrm{kDa}$ band in the induced cells, indicating that the recombinant OaLypla1H and OaLypla1W were successfully expressed in the transformed E. coli BL21 (DE3) cells following IPTG induction (Figure 4A). The recombinant OaLyplaH protein was purified and detected by SDS-PAGE and Western blots using a commercial His tag antibody and showed the same molecular weight of approximately $25 \mathrm{kDa}$, including the molecular weight of $\mathrm{His}_{6}$-tag (Figure 4B,C).
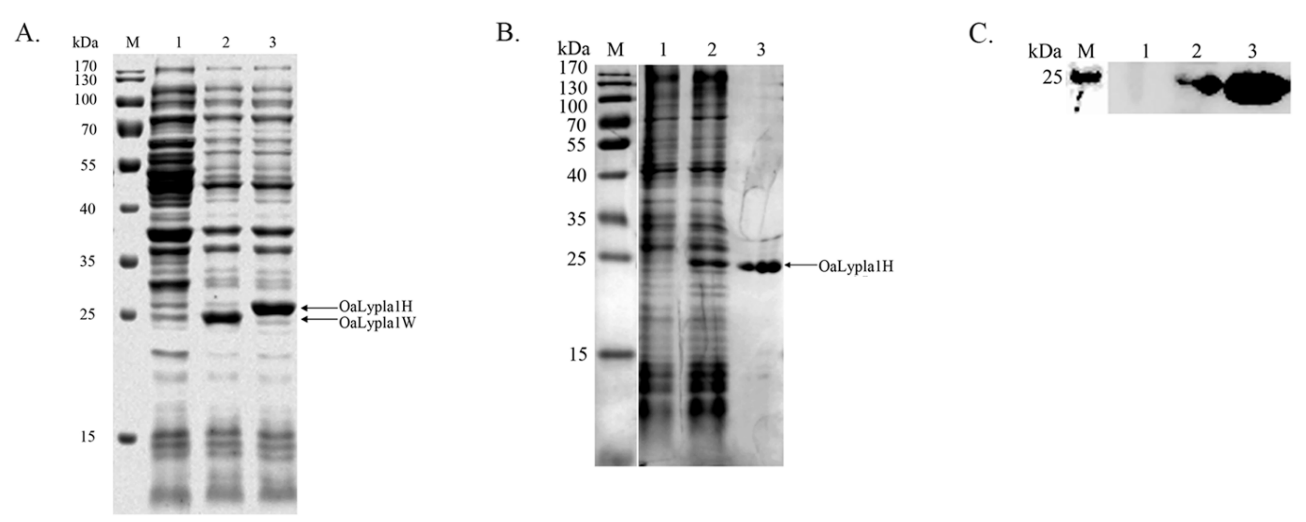

Figure 4. Expression and purification analysis of the recombinant OaLypla1 protein. (A) Expression analysis of the recombinant OaLypla1 by SDS-PAGE. M: protein marker (Thermo, Waltham, MA, USA); lane 1: total proteins from the uninduced pET-30a-LYPLA1-W cells; lane 2: total proteins from the induced pET-30a-LYPLA1-W cells (expressing OaLypla1 with no $\mathrm{His}_{6}$-tag); lane 3: total proteins from the induced pET-30a-LYPLA1-H cells (expressing OaLypla1 with a His 6 -tag) showing the shifted band due to the $\mathrm{His}_{6}$-tag; (B) Purification analysis of the recombinant OaLypla1H by SDS-PAGE. M: protein marker (Thermo, Waltham, MA, USA); lane 1: total proteins from the uninduced pET-30a-LYPLA1-H cells; lane 2: total proteins from the induced pET-30a-LYPLA1-H cells; lane 3: the purified recombinant protein OaLypla1H; (C) Expression and purification analysis of the recombinant OaLypla1H by Western blotting. M: protein marker (Thermo, Waltham, MA, USA); lane 1: total proteins from the uninduced pET-30a-LYPLA1-H cells; lane 2: total proteins from the induced pET-30a-LYPLA1-H cells; lane 3: the purified recombinant protein OaLypla1H. 


\subsection{Activity Assay}

The phospholipase activity was determined by the egg yolk/agarose diffusion test. Phospholipase A is able to degrade micellar lecithins and cephalins into dissolvable lyso compounds and fatty acids, which leads to a clearing of egg yolk suspension in an agarose gel plate. Transparent rings will develop around the holes in which the phospholipase A is added after the egg yolk suspension is incorporated into the agarose gels [38]. The results of the egg yolk/agarose diffusion test showed that transparent rings were visualized around the holes after purified recombinant OaLypla1H was added. The diameters of the transparent rings were larger with increased concentrations of OaLypla1H. There were no transparent rings in the BSA and OaPDCD10 groups (Figure 5).
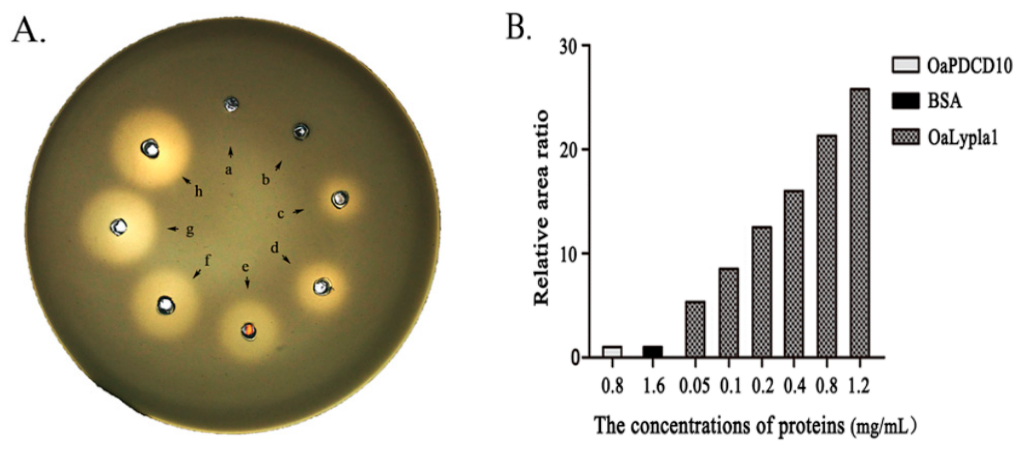

Figure 5. Phospholipase activity assay of the OaLypla1 protein. (A) Egg yolk/agarose diffusion test: a, $0.8 \mathrm{mg} / \mathrm{mL}$ OaPDCD10 with a $\mathrm{His}_{6}$-tag; b, $1.6 \mathrm{mg} / \mathrm{mL} \mathrm{BSA}$; and c-h, 0.05, 0.1, 0.2, 0.4, 0.8 and $1.2 \mathrm{mg} / \mathrm{mL}$ of OaLypla1H; (B) Relative area ratio. The results were calculated as a measure of the relative area ratio with the area of the hole in the center as $100 \%$.

\subsection{Specificity of the Monoclonal Antibody (mAb)}

A hybridoma cell line secreting mAbs against OaLypla1 was obtained as described in the methods and named OaLypla1-4A3. The results of the Western blotting analyses showed that the mAbs were able to bind the recombinant OaLypla1 and native OaLypla1 proteins extracted from kidney (Figure 6).
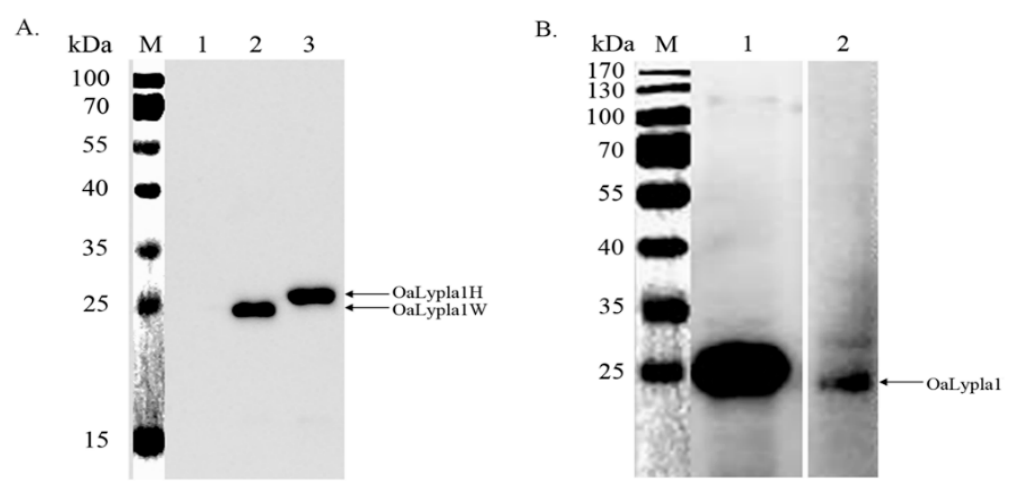

Figure 6. Immunoassay specificity of the monoclonal antibody against OaLypla1. (A) Immunoassay specificity against the recombinant OaLypla1. M: protein marker (Thermo, Waltham, MA, USA); lane 1: total proteins from the uninduced pET-30a-LYPLA1-W cells; lane 2: total proteins from the induced pET-30a-LYPLA1-W cells; lane 3: total proteins from the induced pET-30a-LYPLA1-H cells; (B) Immunoassay specificity against the native OaLypla1. M: protein marker (Thermo, Waltham, MA, USA); lane 1: total proteins from the induced pET-30a-LYPLA1-H cells as a positive control; lane 2: total proteins extracted from the kidney of $O$. aries. The pET-30a-LYPLA1-W cells were induced to express the recombinant OaLypla1 with no $\mathrm{His}_{6}$-tag, and the pET-30a-LYPLA1-H cells expressed OaLypla1 fused with a $\mathrm{His}_{6}$-tag. 


\subsection{Tissue Distribution of OaLypla1}

To determine the tissue expression profiles of OaLypla1, qPCR and Western blot analyses were carried out to examine the tissue distribution of OaLypla1 with the primers (Table 1) and the mAb prepared as described above. As shown in Figure 7A, the OaLypla1 mRNA was detected in the liver, spleen, lung, kidney and WBCs, with the highest expression in the kidney. OaLypla1 protein was detected in the liver, spleen, lung and kidney but not in the WBCs (Figure 7B) by Western blotting.

A.

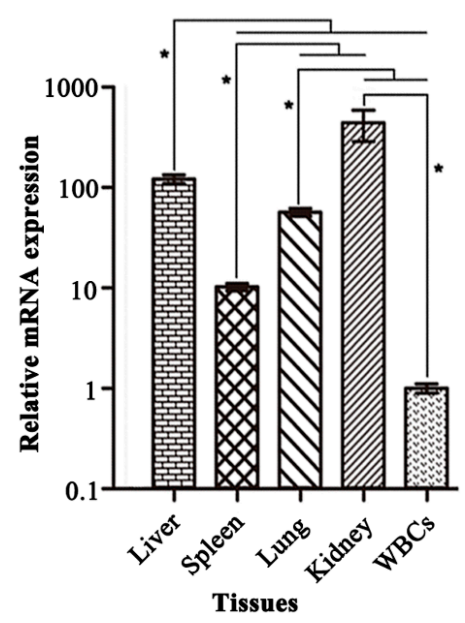

B.

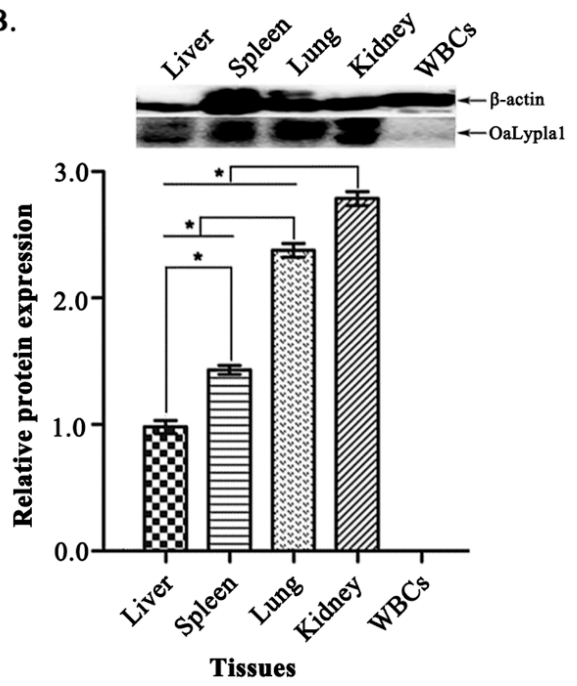

Figure 7. Tissue distribution of OaLypla1. (A) The tissue distribution of OaLypla1 determined by quantitative real-time PCR. The mRNA levels in tissues were normalized with $\beta$-actin; (B) OaLypla1 protein detected in the tissues using Western blotting. Statistical differences among liver, spleen, lung, kidney, and white blood cells were determined by one-way analysis of variance (ANOVA) using SPSS 13.0 software (IBM, Armonk, NY, USA). Data are presented as the mean relative expression \pm SD $(n=3)$. An asterisk indicates a statistically significant difference $(* p<0.05)$. WBCs: white blood cells.

Table 1. Primers used in this study.

\begin{tabular}{|c|c|c|}
\hline Primer & Object & Sequence $\left(5^{\prime}-3^{\prime}\right)$ \\
\hline GSP & $5^{\prime}-\mathrm{RACE}$ & 5'-TCTTGCCATAAGTTAGATCTTGCTG-3' \\
\hline NGSP & 5'-RACE & 5'-GTCACTTCCATCATCAAATAGCACC-3' \\
\hline (20)KLS & ORF amplification & 5'-CATATGTGCGGCAATAACATGTCGGC-3' \\
\hline (20)KLHisA & ORF amplification & 5'-CTCGAGGTCAATGGGAGGTAGGAGCTTATC-3' \\
\hline (20)KLWA & ORF amplification & $5^{\prime}$-CTCGAGTCAGTCAATGGGAGGTAGGAGCTTATC- ${ }^{\prime}$ \\
\hline$\beta$-actin-S & qPCR & $5^{\prime}$-CCCAAGGCCAACCGTGAGAAGATGA-3' \\
\hline$\beta$-actin-A & qPCR & 5'-CGAAGTCCAGGGCCACGTAGCAGAG-3' \\
\hline OaLypla1S & gPCR & 5'-CCTATTGGTGGCGTGAACAGAGAC-3' \\
\hline OaLypla1A & qPCR & 5'-GAACTGTGCATCATGCCTGCGTAG-3' \\
\hline
\end{tabular}

The letters marked by the single underline in the primer sequences stood for the restriction sites of Nde I (CATATG) and Xho I (CTCGAG).

\subsection{OaLypla1 Expression Profiles after Challenge with Virulent and Avirulent Brucella Strains}

The expression profiles of OaLypla1 in the buffy coats of $O$. aries challenged with virulent and avirulent Brucella strains were analyzed using $\mathrm{PPCR}$, as shown in Figure 8. Compared with the untreated control group, the transcription levels of OaLypla1 were down-regulated in both the BmF-challenged group and the S2-challenged group from 3 to $75 \mathrm{dpc}$. In the S2-challenged group, the level of OaLypla1 transcription increased from 3 to $14 \mathrm{dpc}$, reached a peak at $14 \mathrm{dpc}$, and then decreased, with the lowest level at $75 \mathrm{dpc}$. In the BmF-challenged group, the OaLypla1 levels remained at a low 
level compared with the S2-challenged group. However, at $21 \mathrm{dpc}$, OaLypla1 in the BmF-challenged group was much higher than in the S2-challenged group.

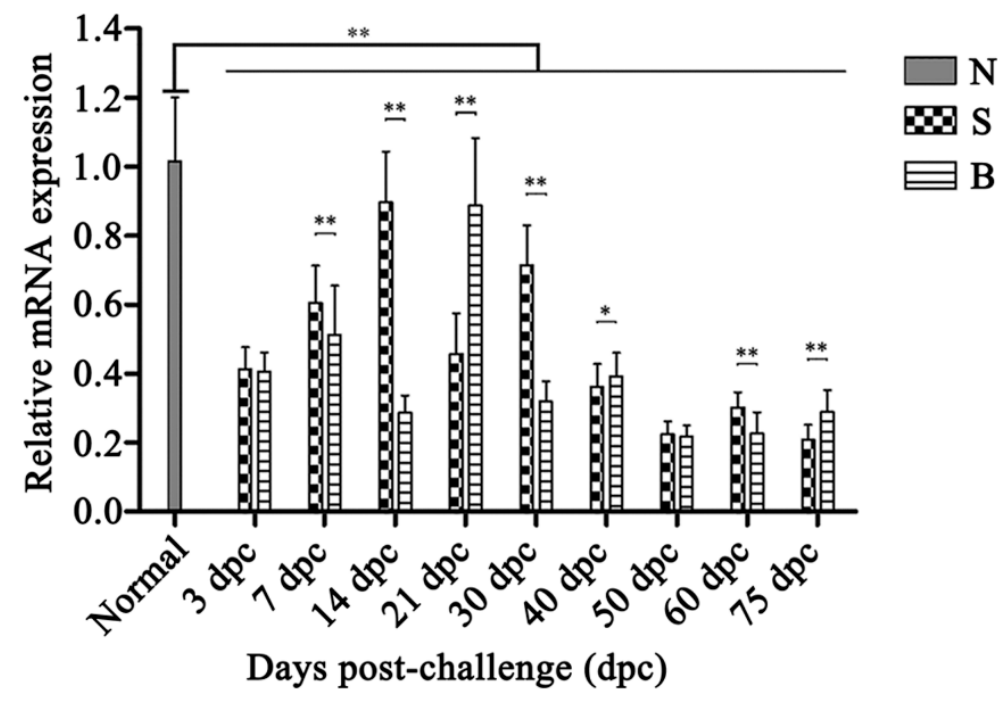

Figure 8. Differential expression of OaLypla1 from buffy coats of $O$. aries challenged with different virulent Brucella strains. N: the normal sheep group; S: the group inoculated with the avirulent Brucella suis S2 strain; and B: the group challenged with the virulent field strain Brucella melitensis. Relative expression was calculated by the $2^{-\Delta \Delta C t}$ method using $O$. aries $\beta$-actin as an endogenous control. Statistical differences among the groups were determined by a one-way analysis of variance (ANOVA) using SPSS 13.0 software. Data are presented as the mean relative expression \pm SD $(n=3)$ $\left({ }^{*} p<0.05,{ }^{* *} p<0.01\right)$.

\section{Discussion}

Lysophospholipases are critical enzymes to regulate the multifunctional lysophospholipids. In this study, we focused on the OaLypla1 gene screened from a time course SSH cDNA library constructed in our lab before. The full-length cDNA of OaLypla1 was cloned and sequenced for the first time. The OaLypla1 gene was characterized at the molecular level and the recombinant protein was produced to identify its functional activities in vitro. Further, the tissue-specific expression of OaLypla1 was determined, and the bacterial stress responses of OaLypla1 were investigated after sheep were infected with Brucella. This was the first report about the LYPLA1 gene from sheep (Ovis aries).

It is reported that LYPLA1 of murine represents a member of the serine hydrolase family with Ser ${ }^{119}$, Asp ${ }^{174}$, and $\mathrm{His}^{208}$ composing the catalytic triad [39], and site-directed mutagenesis indicated that mutation of each residue to Ala abolished LYPLA1 activity [37,39]. The protein sequence analysis showed that OaLypla1 has the same catalytic triad with LYPLA1 from murine, rat and human. To confirm the bioactivity of the lipase catalytic center ${ }^{117}{ }^{G F S Q G}{ }^{121}$ in the OaLypla1 protein, the phospholipase activity of the recombinant OaLypla1 was identified using the egg yolk/agarose diffusion test in this study. This is a sensitive and simple test that has been used frequently for phospholipase A activity assay in recent years [40-44]. The purified recombinant OaLypla1 was also used to generate an anti-OaLypla1 $\mathrm{mAb}$ that was confirmed to specifically bind to the recombinant and native OaLypla1 proteins.

The tissue distribution of the OaLypla1 gene at both the mRNA and protein levels was measured using qPCR and Western blots, respectively. OaLypla1 was detected in all of the examined tissues, showing the highest mRNA expression in the kidney. The result was similar to the previous reports [2,4]. OaLypla1 was constitutively expressed in tissues at the transcriptional level, suggesting that OaLypla1 is a ubiquitously expressed gene and is a critical molecule that could potentially be involved in numerous physiological functions. OaLypla1 protein was not detected in WBCs, which 
was consistent with the low OaLypla1 mRNA abundance in WBCs. As described in a previous study, gene expression levels cannot be determined only by mRNA abundance based on the mRNA-protein correlation [45], and post-transcriptional processing would also affect the expression levels of genes. The different mRNA and protein abundances resulting from the same gene emphasize the importance of integrative analysis of transcription and translation [46].

LYPLA1 has been cloned from rat [4], murine [37], and human [2]. The lysophospholipase, phospholipase A2 and thioesterase activities were identified [21]. However, there is no investigation about the relationship between LYPLA1 and infection of bacteria. The LYPLA1 gene from Ovis aries cloned in this study may take apart in the immune response of the host towards the infection of bacteria.

Brucellosis is a major zoonotic disease worldwide. Brucella can evade the host immune response to survive and reproduce in host cells. Currently, live attenuated vaccines are used to eradicate brucellosis in cattle, sheep and goats. Infection by both the live attenuated vaccines and by the virulent strain will cause similar immune responses, such as stimulation of Th1 responses [47]. As a consequence, it is impossible to distinguish between vaccinated animals and infected ones using the available serological tests at present [48].

It was reported that the expression profiles and releases of LYPLA1 are related to immunological stimulation and decreased LYPLA1 levels likely contribute to macrophage responses to pro-inflammatory stimuli. Along with the mRNA and protein levels of LYPLA1 decreased in LPS-stimulated RAW 264.7 cells, LYPLA1 released from RAW 264.7 cells into the culture medium was significantly increased. Inhibition of circulating LYPLA1 activity may be an effective treatment strategy for inflammation [36]. In the present study, the expression profiles of OaLypla1 were analyzed using $\mathrm{qPCR}$, and the results confirmed that the transcriptional levels of OaLypla1 in WBCs were down-regulated by infection of Brucella compared with the uninfected sheep. Down-regulation of OaLypla1 expression in WBCs from the infected groups showed that LYPLA1 was perhaps involved in the immune response to the stimulation, and indicated that the transcription of the LYPLA1 gene is inducible, which is consistent with the previous report [36]. There are hardly any studies about the relationship between the expression profile of LYPLA1 and bacterial infection. LYPLA1 can hydrolyze lysophospholipids and participate in the phosphatidylcholine (PLC) pathway [39,49]. Thus, we speculated that the decreased LYPLA1 might result in the increasing level of LPLs, which are able to attract and activate macrophages and T or B cells, influence their interactions with other types of cells, and promote and modulate immune responses [50]. The exact mechanism of this phenomenon needs to be further studied. In addition, we also determined that the transcription patterns of the OaLypla1 gene in buffy coats were different between sheep infected with the avirulent Brucella suis S2 vaccine strain and those infected with the virulent Brucella melitensis field strain. Whether OaLypla1 can be a biomarker distinguishing between virulent Brucella infection and the avirulent Brucella vaccine inoculation and the relationship between OaLypla1 and brucellosis need to be further studied in the future.

\section{Materials and Methods}

\subsection{Animals and Cells}

All of the sheep used in this research were purchased from Sangang farm (Jilin Province, China) and had no infectious diseases. Female BALB/c mice and sheep received food and water ad libitum [51]. All the animal experiments were carried out abiding by the provisions of EU animal management practices (24 November 1986), and approved by the Animals Ethics Committee of Jilin University of China in accordance with the Jilin university ethnic committee guideline for the Care and Use of Laboratory Animal (No. SCXK 2015-0004, 7 January 2015). The avirulent strain of Brucella (S2) was purchased from Harbin Pharmaceutical Group Bioengineering Co., Ltd. (Haerbin, China). The isolated and identified virulent strain of Brucella, myeloma SP2/0 cells, Escherichia coli DH5 $\alpha$ competent cells 
and E. coli BL21 (DE3) cells were provided by the Key Laboratory of Zoonosis Research, Ministry of Education, Jilin University (Jilin, China).

\subsection{Total RNA Isolation}

Total RNA was isolated as described previously [48]. Briefly, the anticoagulant-containing blood collected from O. aries was centrifuged at $800 \times g$ for $15 \mathrm{~min}$ at $4{ }^{\circ} \mathrm{C}$ to extract the buffy coats. The buffy coats were used for total RNA extraction using TRIzol Reagent (Invitrogen, Carlsbad, CA, USA) following the manufacturer's instructions. DNA and protein contamination was removed using recombinant DNase I (RNase-free) (TaKaRa, Dalian, China) and an RNeasy MinElute Cleanup Kit (Qiagen, Hilden, Germany).

\subsection{5'-RACE and Sequence Assembly}

To obtain the full-length cDNA sequence, the purified total RNA and a SMARTer ${ }^{\mathrm{TM}}$ RACE cDNA Amplification Kit (Clontech, Mountain View, CA, USA) were used. A set of gene-specific primers was designed (Table 1) and named GSP (gene-specific primer) and NGSP (nested gene-specific primer). The PCR amplifications were performed using the following protocol. Briefly, $20 \mu \mathrm{L}$ reaction volumes containing 5'-RACE-Ready cDNA as the template, primers $(0.4 \mu \mathrm{L}$ of $10 \mu \mathrm{M}$ GSP and $2.0 \mu \mathrm{L} \mathrm{UPM}$ provided by the kit), $0.4 \mu \mathrm{L} 10 \mathrm{mM}$ dNTPs, and $0.4 \mu \mathrm{L} 50 \times$ Advantage Polymerase mix were prepared. The conditions were $94{ }^{\circ} \mathrm{C}$ for $3 \mathrm{~min} ; 20$ cycles of $30 \mathrm{~s}$ at $94{ }^{\circ} \mathrm{C}, 30 \mathrm{~s}$ at $54.1^{\circ} \mathrm{C}, 3 \mathrm{~min}$ at $72{ }^{\circ} \mathrm{C}$; then a final extension at $72{ }^{\circ} \mathrm{C}$ for $5 \mathrm{~min}$. The products were diluted 1:50 and used as template cDNA for the nested PCR. The nested PCR amplification was similar to the first PCR amplification except for the primers and template. The PCR conditions were $3 \mathrm{~min}$ at $94^{\circ} \mathrm{C} ; 25$ cycles of $30 \mathrm{~s}$ at $94^{\circ} \mathrm{C}, 30 \mathrm{~s}$ at $61.1^{\circ} \mathrm{C}$, $3 \mathrm{~min}$ at $72{ }^{\circ} \mathrm{C}$; then the last extension at $72{ }^{\circ} \mathrm{C}$ for $5 \mathrm{~min}$. The PCR products were visualized on a $1 \%$ agarose gel stained with ethidium bromide. After purification and ligation into the $\mathrm{pMD}^{\mathrm{TM}} 18-\mathrm{T}$ vector (TaKaRa, Dalian, China), the target DNA products were transformed into E. coli DH5 $\alpha$ competent cells and sequenced by Shanghai Sangon Biological Engineering Technology \& Service Co., Ltd. (Shanghai, China). The obtained sequences and the partial cDNA sequence identified from the SSH cDNA library were assembled to obtain the full-length cDNA sequence of OaLypla1.

\subsection{Sequence Verification and Analysis}

A homology search for the assembled sequence of OaLypla1 was performed using the BLAST search programs at NCBI [52]. The molecular weight of the putative protein was predicted using the Expert Protein Analysis System [53]. Characteristic domains or motifs were identified using the Motif scan program [54]. The amino acid sequences of LYPLA1 from various species were retrieved from NCBI and analyzed using ClustalW version 1.83 . The phylogenetic tree was constructed based on the amino sequence alignment with the neighbor joining method from the MEGA version 4.1 program.

\subsection{Cloning of OaLypla1}

The open reading frame (ORF) of the Oalylpla1 transcript was amplified using the forward primer (20)KLS with a NdeI recognition site and the reverse primers (20)KLHisA (for the $6 \times$ His tag fusion) and (20)KLWA (for no fusion) with a XhoI recognition site at their $5^{\prime}$-ends, as listed in Table 1. The recombinant plasmids constructed in 4.3 were used as the template with Ex Taq (TaKaRa, Dalian, China), and the PCR reactions were performed at $94{ }^{\circ} \mathrm{C}$ for $30 \mathrm{~s}$; then at $94{ }^{\circ} \mathrm{C}$ for $30 \mathrm{~s}, 60{ }^{\circ} \mathrm{C}$ for $30 \mathrm{~s}, 72{ }^{\circ} \mathrm{C}$ for $60 \mathrm{~s}$ for 32 cycles; and the final extension at $72{ }^{\circ} \mathrm{C}$ for $10 \mathrm{~min}$. The PCR products were separated, purified and ligated into the $\mathrm{pMD}^{\mathrm{TM}} 19-\mathrm{T}$ Simple vector and transformed into E. coli $\mathrm{DH} 5 \alpha$ cells. The cells with recombinant plasmids were confirmed with PCR using M13 forward and reverse primers, and the plasmids were then sequenced. 


\subsection{Expression and Purification of the Recombinant OaLypla1 Protein}

The recombinant plasmids were digested with NdeI and XhoI restriction enzymes, and the products were purified and ligated into the restriction enzyme-digested pET-30a vectors. The recombinant expression plasmids were transformed into E. coli BL21 (DE3), and the cells carrying the plasmid were named pET-30a-LYPLA1-H and pET-30a-LYPLA1-W. A single transformant colony was grown overnight in $5 \mathrm{~mL}$ Luria-Bertani (LB) medium containing $50 \mu \mathrm{g} / \mathrm{mL}$ kanamycin at $37^{\circ} \mathrm{C}$, and the protein expression of OaLypla1H (OaLypla1 with $\mathrm{His}_{6}$-tag) and OaLypla1W (OaLypla1 with no $\mathrm{His}_{6}$-tag) was separately induced by adding isopropyl $\beta$-D-1-thiogalactopyranoside (IPTG) at a final concentration of $1.5 \mathrm{mM}$ at $37{ }^{\circ} \mathrm{C}$ for $6.5 \mathrm{~h}$. Total protein lysates extracted from the induced pET-30a-LYPLA1-H and pET-30a-LYPLA1-W cells were analyzed using 12\% sodium dodecyl sulfate-polyacrylamide gel electrophoresis (SDS-PAGE).

Protein expression of OaLypla1H in $200 \mathrm{~mL}$ fresh LB medium was induced by adding IPTG at a final concentration of $1.5 \mathrm{mM}$ at $37^{\circ} \mathrm{C}$ for $6.5 \mathrm{~h}$. The induced pET-30a-LYPLA1-H cells were harvested and resuspended in binding buffer $(20 \mathrm{mM}$ sodium phosphate, $30 \mathrm{mM}$ imidazole, $0.5 \mathrm{M}$ $\mathrm{NaCl}, \mathrm{pH}$ 7.4) [48]. The supernatant was collected by centrifugation at $12,000 \times \mathrm{g}$ for $30 \mathrm{~min}$ at $4{ }^{\circ} \mathrm{C}$ after the resuspended cells were sonicated. Then, the supernatant was loaded onto a HisTrap ${ }^{\mathrm{TM}} \mathrm{FF}$ crude (GE Healthcare, Pittsburgh, PA, USA) resin, and after washed with binding buffer for 10 times of column volume, the OaLypla1H protein was eluted with elution buffer $(20 \mathrm{mM}$ sodium phosphate, $0.5 \mathrm{M} \mathrm{NaCl}, 0.5 \mathrm{M}$ imidazole, $\mathrm{pH}$ 8.0). The purified protein was dialyzed using 0.01 M PBS (pH 8.0).

The purified protein OaLypla1H was run on 12\% SDS-PAGE with a protein marker (Thermo, Waltham, MA, USA) and stained with Coomassie brilliant blue R250. The molecular mass and the purity of the purified protein were assessed. Western blotting was performed with a commercial anti-His tag antibody (Abcam, Cambridge, MA, USA) to demonstrate that the recombinant OaLypla1H protein had been expressed and purified.

\subsection{Phospholipase Activity Assay}

The phospholipase activity of the OaLypla1H protein was analyzed as described in previous reports [38,55-57]. Briefly, the egg yolk was diluted $1: 4$ with $0.85 \% \mathrm{NaCl}$, and the supernatant (Buffer $\mathrm{A})$ was collected by centrifugation at $3500 \mathrm{rpm}$ for $2 \mathrm{~min}$. Agarose $(0.6 \mathrm{~g})$ was dissolved in $100 \mathrm{~mL} 0.05 \mathrm{M}$ $\mathrm{NaAc}(\mathrm{pH} 7.5)$ at $120^{\circ} \mathrm{C}$ for $10 \mathrm{~min}$. Buffer $\mathrm{A}(3 \mathrm{~mL})$ and $0.01 \mathrm{M} \mathrm{CaCl}_{2}(1 \mathrm{~mL})$ were added to the $0.6 \%$ agarose $\mathrm{NaAc}$ solution when the temperature cooled to $50{ }^{\circ} \mathrm{C}$, and the solution was then poured into glass plates $(\phi 150 \mathrm{~mm})$, and a hole was punched after the agarose solidified. A $0.85 \% \mathrm{NaCl}$ solution $(50 \mu \mathrm{L})$ containing different concentrations of purified OaLypla1H $(0.05-1.2 \mathrm{mg} / \mathrm{mL})$ was added into the holes of the agarose plates, and $50 \mu \mathrm{L}$ of $0.85 \% \mathrm{NaCl}$ containing $1.6 \mathrm{mg} / \mathrm{mL}$ of the bovine serum albumin (BSA) and $0.8 \mathrm{mg} / \mathrm{mL}$ of the recombinant programmed cell death 10 of Ovis aries (OaPDCD10) with a $6 \times$ His tag [58] were applied as negative controls. The plates were incubated at $37{ }^{\circ} \mathrm{C}$ for $24 \mathrm{~h}$. The diameters of visible transparent circles appearing as a result of the phospholipase activity of OaLypla1H were measured.

\subsection{Preparation of the mAb against the OaLypla1 Protein}

Eight- to ten-week-old female BALB/C mice were immunized in the footpad with $100 \mu \mathrm{g}$ of OaLypla1H emulsified with an equal volume of complete Freund's adjuvant (CFA, Sigma, St. Louis, MO, USA) or incomplete Freund's adjuvant (IFA, Sigma, St. Louis, MO, USA) based on a previous report [59]. The mice were housed with adequate food and water. Four days after the fourth immunization, the spleen cells isolated from the immunized mice were fused with myeloma cells (SP2/0) at a ratio of 10:1 in the presence of PEG1000. Then, the fused cells were cultured in 96-well cell culture plates using 20\% (v/v) FBS/HAT (Sigma, St. Louis, MO, USA) medium, which was changed once per 4 days. Two weeks later, the hybridoma cells secreting the anti-OaLypla1 mAb were screened 
and cloned by limiting dilution at least three times. The culture supernatant of the positive hybridoma cells was used for the next experimental study.

\subsection{Specificity Analysis}

The specificity of the mAb was analyzed using Western blotting as described in a previous report [48]. Untagged OaLypla1W, OaLypla1H with a $\mathrm{His}_{6}$-tag and whole proteins from sheep kidneys were used to confirm the specificity of the $\mathrm{mAb}$ binding by Western blotting. Briefly, protein samples were extracted from bacteria or sheep kidneys, separated with $12 \%$ SDS-PAGE, and probed with the anti-OaLypla1 mAb (dilution 1:20) after transfer to a PVDF membrane (Millipore, Billerica, MA, USA). Then, the horseradish peroxidase-labeled goat anti-mouse IgG (dilution 1:2000) was incubated with the PVDF membrane. The membrane detection was performed with a BeyoECL Plus kit (Beyotime, Shanghai, China) using the ECL detection system (DNR, Jerusalem, Israel).

\subsection{Tissue Distribution}

Tissue distribution of OaLypla1 in the liver, spleen, lung, kidney and white blood cells (WBCs) of sheep was analyzed by quantitative real-time PCR (qPCR) and Western blotting. Total RNA was extracted from different tissues and organs of 3 healthy sheep using TRIzol Reagent (Invitrogen, Carlsbad, CA, USA) following the manufacturer's instructions. One microgram of total RNA was used to synthesize cDNA using a PrimeScript ${ }^{\mathrm{TM}}$ RT reagent kit with gDNA Eraser (Perfect Real Time) (TaKaRa, Dalian, China). The qPCR reaction was carried out in a total volume of $20 \mu \mathrm{L}$ containing $10 \mu \mathrm{L}$ of FastStart Universal SYBR Green Master (ROX) (Roche, Basel, Switzerland), $0.6 \mu \mathrm{L}$ of the forward primer $(10 \mu \mathrm{M}), 0.6 \mu \mathrm{L}$ of the reverse primer $(10 \mu \mathrm{M})$, and $1.5 \mu \mathrm{L}$ of 5 -fold diluted cDNAs. The qPCR cycling protocol was $95^{\circ} \mathrm{C}$ for $10 \mathrm{~min}$ and 40 cycles of $15 \mathrm{~s}$ at $95^{\circ} \mathrm{C}, 62^{\circ} \mathrm{C}$ for $35 \mathrm{~s}$ and $72{ }^{\circ} \mathrm{C}$ for $32 \mathrm{~s}$. Samples were normalized with $\beta$-actin, and the relative transcription level of OaLypla1 was calculated using the $2^{-\Delta \Delta C t}$ method. Each assay was repeated in triplicate.

The total proteins from different tissues (liver, spleen, lung, kidney and WBCs) were extracted using RIPA lysis buffer (Beyotime, Shanghai, China) with $10 \mu \mathrm{L}$ PMSF according to the manufacturer's instructions. The total protein concentration was measured by the Bradford method [60] using a Bradford protein assay kit (Bio-Rad, Hercules, CA, USA). Total proteins (125 $\mu \mathrm{g})$ from different sheep tissues and organs were used for Western blot analysis with the generated anti-OaLypla1 mAb following a standard protocol [48], and $\beta$-actin was used as an internal control. Optical densities of OaLypla1 and $\beta$-actin were calculated using Quantity One software (Bio-Rad, Hercules, CA, USA). Significant differences were determined by one-way analysis of variance (ANOVA) using the SPSS 13.0 software (IBM, Armonk, NY, USA).

\subsection{Relative Transcript Level Analysis of OaLypla1 in Buffy Coats after Challenge with Virulent and Avirulent Brucella Strains}

For differential expression analysis of OaLypla1, qPCR was employed with a pair of gene-specific primers (OaLypla1S and OaLypla1A) listed in Table 1, and $\beta$-actin (GenBank accession number U39357) was used as an internal control [48]. As described in a previous study [61], 9 sheep were randomly divided into three groups $(n=3)$. Three sheep were challenged with a virulent Brucella melitensis field strain $(\mathrm{BmF})$ as the BmF-challenged group, and three sheep were inoculated with an avirulent Brucella suis S2 vaccine strain (S2) as the S2-inoculated group. Each sheep was injected with a total dose of $2.2 \times 10^{9} \mathrm{cfu}$ of bacteria. In addition, three other sheep were treated with the same volume of sterile $0.85 \% \mathrm{NaCl}$ as the normal control group. The buffy coat samples from three individuals in each group were obtained at 3, 7, 14, 21, 30, 40, 50, 60 and 75 days post-challenge (dpc). Extracting the total RNAs and performing the qPCR for OaLypla1 differential expression analysis in buffy coats were performed as described in 4.10 above. Each assay was repeated in triplicate. 


\section{Conclusions}

This study identified and characterized a novel full-length cDNA of the LYPLA1 gene from Ovis aries (OaLypla1), and the corresponding protein was expressed, purified and characterized. OaLypla1 was widely expressed in different tissues at both the mRNA and protein levels. qPCR analysis showed that the expression of OaLypla1 in the white blood cells of Ovis aries was down-regulated after infected with Brucella. This study provides fundamental data for further investigations exploring the relationship between Brucella infection and the expression patterns of OaLypla1 and the possible functions of OaLypla1 during Brucella infection.

Acknowledgments: This work was supported by the National Natural Science Foundation of China (No. 30901070), the Science \& Technology Development Project of Jilin Province, China (No. 20150204078NY) and the Graduate Innovation Fund of Jilin University (No. 2015041).

Author Contributions: Hong-Lin Ren conceived and designed the experiments; Nan-Nan Liu, Zeng-Shan Liu, Pan Hu and Ying Zhang performed the experiments; Yong-Jie Yang, Shi-Ying Lu, Yan-Song Li, and Yu Zhou analyzed the data; Dong-Song Zhang contributed materials and analysis tools; and Nan-Nan Liu, Zeng-Shan Liu, Pan Hu, Ying Zhang and Hong-Lin Ren wrote the paper.

Conflicts of Interest: The authors declare no conflict of interest.

\section{References}

1. Portilla, D.; Crew, M.D.; Grant, D.; Serrero, G.; Bates, L.M.; Dai, G.; Sasner, M.; Cheng, J.; Buonanno, A. cDNA cloning and expression of a novel family of enzymes with calcium-independent phospholipase A2 and lysophospholipase activities. J. Am. Soc. Nephrol. 1998, 9, 1178-1186. [PubMed]

2. Wang, A.; Yang, H.C.; Friedman, P.; Johnson, C.A.; Dennis, E.A. A specific human lysophospholipase: cDNA cloning, tissue distribution and kinetic characterization. Biochim. Biophys. Acta 1999, 1437, 157-169. [CrossRef]

3. Duncan, J.A.; Gilman, A.G. A cytoplasmic acyl-protein thioesterase that removes palmitate from G protein alpha subunits and p21 RAS. J. Biol. Chem. 1998, 273, 15830-15837. [CrossRef] [PubMed]

4. Sugimoto, H.; Hayashi, H.; Yamashita, S. Purification, cDNA cloning, and regulation of lysophospholipase from rat liver. J. Biol. Chem. 1996, 271, 7705-7711. [PubMed]

5. Blaskovic, S.; Adibekian, A.; Blanc, M.; van der Goot, G.F. Mechanistic effects of protein palmitoylation and the cellular consequences thereof. Chem. Phys. Lipids 2014, 180, 44-52. [CrossRef] [PubMed]

6. Wang, A.; Dennis, E.A. Mammalian lysophospholipases. Biochim. Biophys. Acta 1999, 1439, 1-16. [CrossRef]

7. Moolenaar, W.H.; Hla, T. SnapShot: Bioactive lysophospholipids. Cell 2012, 148, 378-378.e2. [CrossRef] [PubMed]

8. Sevastou, I.; Kaffe, E.; Mouratis, M.A.; Aidinis, V. Lysoglycerophospholipids in chronic inflammatory disorders: The PLA 2 /LPC and ATX/LPA axes. Biochim. Biophys. Acta 2013, 1831, 42-60. [CrossRef] [PubMed]

9. Sakai, M.; Miyazaki, A.; Hakamata, H.; Kobori, S.; Shichiri, M.; Horiuchi, S. Endocytic uptake of lysophosphatidylcholine mediated by macrophage scavenger receptor plays a major role in oxidized low density lipoprotein-induced macrophage growth. J. Atheroscler Thromb. 1996, 2, 81-86. [CrossRef] [PubMed]

10. Sakai, M.; Miyazaki, A.; Hakamata, H.; Sasaki, T.; Yui, S.; Yamazaki, M.; Shichiri, M.; Horiuchi, S. Lysophosphatidylcholine plays an essential role in the mitogenic effect of oxidized low density lipoprotein on murine macrophages. J. Biol. Chem. 1994, 269, 31430-31435. [PubMed]

11. Ngwenya, B.Z.; Yamamoto, N. Activation of peritoneal macrophages by lysophosphatidylcholine. Biochim. Biophys. Acta 1985, 839, 9-15. [CrossRef]

12. Burdzy, K.; Munder, P.G.; Fischer, H.; Westphal, O. Increase in the Phagocytosis of Peritoneal Macrophages by Lysolecithin. Z. Naturforschung B 1964, 19, 1118-1120.

13. Asaoka, Y.; Oka, M.; Yoshida, K.; Sasaki, Y.; Nishizuka, Y. Role of lysophosphatidylcholine in T-lymphocyte activation: Involvement of phospholipase A2 in signal transduction through protein kinase C. Proc. Natl. Acad. Sci. USA 1992, 89, 6447-6451. [CrossRef] [PubMed] 
14. Asaoka, Y.; Oka, M.; Yoshida, K.; Nishizuka, Y. Lysophosphatidylcholine as a possible second messenger synergistic to diacylglycerol and calcium ion for T-lymphocyte activation. Biochem. Biophys. Res. Commun. 1991, 178, 1378-1385. [CrossRef]

15. Liu-Wu, Y.; Hurt-Camejo, E.; Wiklund, O. Lysophosphatidylcholine induces the production of IL-1 $\beta$ by human monocytes. Atherosclerosis 1998, 137, 351-357. [CrossRef]

16. Wang, A.; Johnson, C.A.; Jones, Y.; Ellisman, M.H.; Dennis, E.A. Subcellular localization and PKC-dependent regulation of the human lysophospholipase A/acyl-protein thioesterase in WISH cells. Biochim. Biophys. Acta 2000, 1484, 207-214. [CrossRef]

17. Aicart-Ramos, C.; Valero, R.A.; Rodriguez-Crespo, I. Protein palmitoylation and subcellular trafficking. Biochim. Biophys. Acta 2011, 1808, 2981-2994. [CrossRef] [PubMed]

18. Iwanaga, T.; Tsutsumi, R.; Noritake, J.; Fukata, Y.; Fukata, M. Dynamic protein palmitoylation in cellular signaling. Prog. Lipid Res. 2009, 48, 117-127. [CrossRef] [PubMed]

19. Tsutsumi, R.; Fukata, Y.; Noritake, J.; Iwanaga, T.; Perez, F.; Fukata, M. Identification of G protein $\alpha$ subunit-palmitoylating enzyme. Mol. Cell. Biol. 2009, 29, 435-447. [CrossRef] [PubMed]

20. Frenal, K.; Kemp, L.E.; Soldati-Favre, D. Emerging roles for protein S-palmitoylation in Toxoplasma biology. Int. J. Parasitol. 2014, 44, 121-131. [CrossRef] [PubMed]

21. Hirano, T.; Kishi, M.; Sugimoto, H.; Taguchi, R.; Obinata, H.; Ohshima, N.; Tatei, K.; Izumi, T. Thioesterase activity and subcellular localization of acylprotein thioesterase 1/lysophospholipase 1. Biochim. Biophys. Acta 2009, 1791, 797-805. [CrossRef] [PubMed]

22. Rocks, O.; Gerauer, M.; Vartak, N.; Koch, S.; Huang, Z.P.; Pechlivanis, M.; Kuhlmann, J.; Brunsveld, L.; Chandra, A.; Ellinger, B.; et al. The palmitoylation machinery is a spatially organizing system for peripheral membrane proteins. Cell 2010, 141, 458-471. [CrossRef] [PubMed]

23. Vartak, N.; Papke, B.; Grecco, H.E.; Rossmannek, L.; Waldmann, H.; Hedberg, C.; Bastiaens, P.I. The autodepalmitoylating activity of APT maintains the spatial organization of palmitoylated membrane proteins. Biophys. J. 2014, 106, 93-105. [CrossRef] [PubMed]

24. Verkruyse, L.A.; Hofmann, S.L. Lysosomal targeting of palmitoyl-protein thioesterase. J. Biol. Chem. 1996, 271, 15831-15836. [PubMed]

25. Boschiroli, M.L.; Foulongne, V.; O'Callaghan, D. Brucellosis: A worldwide zoonosis. Curr. Opin. Microbiol. 2001, 4, 58-64. [CrossRef]

26. Lin, Y.; Xiang, Z.; He, Y. Ontology-based representation and analysis of host-Brucella interactions. J. Biomed. Semant. 2015, 6, 37. [CrossRef] [PubMed]

27. Roop, R.M.; Bellaire, B.H.; Valderas, M.W.; Cardelli, J.A. Adaptation of the brucella to their intracellular niche. Mol. Microbiol. 2004, 52, 621-630. [CrossRef] [PubMed]

28. He, Y.; Reichow, S.; Ramamoorthy, S.; Ding, X.; Lathigra, R.; Craig, J.C.; Sobral, B.W.; Schurig, G.G.; Sriranganathan, N.; Boyle, S.M. Brucella melitensis triggers time-dependent modulation of apoptosis and down-regulation of mitochondrion-associated gene expression in mouse macrophages. Infect. Immun. 2006, 74, 5035-5046. [CrossRef] [PubMed]

29. Celli, J.; de Chastellier, C.; Franchini, D.M.; Pizarro-Cerda, J.; Moreno, E.; Gorvel, J.P. Brucella evades macrophage killing via VirB-dependent sustained interactions with the endoplasmic reticulum. J. Exp. Med. 2003, 198, 545-556. [CrossRef] [PubMed]

30. Pei, J.; Wu, Q.; Kahl-McDonagh, M.; Ficht, T.A. Cytotoxicity in macrophages infected with rough Brucella mutants is type IV secretion system dependent. Infect. Immun. 2008, 76, 30-37. [CrossRef] [PubMed]

31. Fernandez-Prada, C.M.; Zelazowska, E.B.; Nikolich, M.; Hadfield, T.L.; Roop, R.M., II; Robertson, G.L.; Hoover, D.L. Interactions between Brucella melitensis and human phagocytes: Bacterial surface O-Polysaccharide inhibits phagocytosis, bacterial killing, and subsequent host cell apoptosis. Infect. Immun. 2003, 71, 2110-2119. [CrossRef] [PubMed]

32. Gross, A.; Terraza, A.; Ouahrani-Bettache, S.; Liautard, J.P.; Dornand, J. In vitro Brucella suis infection prevents the programmed cell death of human monocytic cells. Infect. Immun. 2000, 68, 342-351. [CrossRef] [PubMed]

33. Buchmeier, N.A.; Heffron, F. Inhibition of macrophage phagosome-lysosome fusion by Salmonella typhimurium. Infect. Immun. 1991, 59, 2232-2238. [PubMed]

34. Eskra, L.; Mathison, A.; Splitter, G. Microarray analysis of mRNA levels from RAW264.7 macrophages infected with Brucella abortus. Infect. Immun. 2003, 71, 1125-1133. [CrossRef] [PubMed] 
35. Rossetti, C.A.; Drake, K.L.; Adams, L.G. Transcriptome analysis of HeLa cells response to Brucella melitensis infection: A molecular approach to understand the role of the mucosal epithelium in the onset of the Brucella pathogenesis. Microbes Infect. 2012, 14, 756-767. [CrossRef] [PubMed]

36. Satou, M.; Nishi, Y.; Yoh, J.; Hattori, Y.; Sugimoto, H. Identification and characterization of acyl-protein thioesterase 1/lysophospholipase I as a ghrelin deacylation/lysophospholipid hydrolyzing enzyme in fetal bovine serum and conditioned medium. Endocrinology 2010, 151, 4765-4775. [CrossRef] [PubMed]

37. Wang, A.; Deems, R.A.; Dennis, E.A. Cloning, expression, and catalytic mechanism of murine lysophospholipase I. J. Biol. Chem. 1997, 272, 12723-12729. [CrossRef] [PubMed]

38. Habermann, E.; Hardt, K.L. A sensitive and specific plate test for the quantitation of phospholipases. Anal. Biochem. 1972, 50, 163-173. [CrossRef]

39. Wang, A.; Loo, R.; Chen, Z.; Dennis, E.A. Regiospecificity and catalytic triad of lysophospholipase I. J. Biol. Chem. 1997, 272, 22030-22036. [CrossRef] [PubMed]

40. Gonzalez-Morales, L.; Diego-Garcia, E.; Segovia, L.; Gutierrez Mdel, C.; Possani, L.D. Venom from the centipede Scolopendra viridis Say: Purification, gene cloning and phylogenetic analysis of a phospholipase A2. Toxicon 2009, 54, 8-15. [CrossRef] [PubMed]

41. Ponce, D.; Lopez-Vera, E.; Aguilar, M.B.; Sanchez-Rodriguez, J. Preliminary results of the in vivo and in vitro characterization of a tentacle venom fraction from the jellyfish Aurelia aurita. Toxins (Basel) 2013, 5, 2420-2433. [CrossRef] [PubMed]

42. Fortes-Dias, C.L.; Ortolani, P.L.; Fernandes, C.A.; Lobo, K.R.; Amaral de Melo, L.; Borges, M.H.; Pazin, W.M.; Neto Mde, O.; Fernandez, R.M.; Fontes, M.R. Insights on the structure of native CNF, an endogenous phospholipase A2 inhibitor from Crotalus durissus terrificus, the South American rattlesnake. Biochim. Biophys. Acta 2014, 1844, 1569-1579. [CrossRef] [PubMed]

43. Gomes, H.L.; Andrich, F.; Fortes-Dias, C.L.; Perales, J.; Teixeira-Ferreira, A.; Vassallo, D.V.; Cruz, J.S.; Figueiredo, S.G. Molecular and biochemical characterization of a cytolysin from the Scorpaena plumieri (scorpionfish) venom: Evidence of pore formation on erythrocyte cell membrane. Toxicon 2013, 74, 92-100. [CrossRef] [PubMed]

44. Lino, R.C.; Martins, F.I.; Florentino, I.F.; Nascimento, M.V.; Galdino, P.M.; Andrade, C.H.; Rezende, K.R.; Menegatti, R.; Costa, E.A. Anti-inflammatory effect of (E)-4-(3,7-dimethylocta-2,6-dienylamino)phenol, a new derivative of 4-nerolidylcatechol. J. Pharm. Pharmacol. 2013, 65, 133-141. [CrossRef] [PubMed]

45. Nie, L.; Wu, G.; Zhang, W.W. Correlation between mRNA and protein abundance in Desulfovibrio vulgaris: A multiple regression to identify sources of variations. Biochem. Biophys. Res. Commun. 2006, 339, 603-610. [CrossRef] [PubMed]

46. Tian, Q.; Stepaniants, S.B.; Mao, M.; Weng, L.; Feetham, M.C.; Doyle, M.J.; Yi, E.C.; Dai, H.; Thorsson, V.; Eng, J.; et al. Integrated genomic and proteomic analyses of gene expression in Mammalian cells. Mol. Cell. Proteom. 2004, 3, 960-969. [CrossRef] [PubMed]

47. Dorneles, E.M.; Teixeira-Carvalho, A.; Araujo, M.S.; Sriranganathan, N.; Lage, A.P. Immune response triggered by Brucella abortus following infection or vaccination. Vaccine 2015, 33, 3659-3666. [CrossRef] [PubMed]

48. Liu, N.N.; Liu, Z.S.; Lu, S.Y.; Hu, P.; Li, Y.S.; Feng, X.L.; Zhang, S.Y.; Wang, N.; Meng, Q.F.; Yang, Y.J.; et al. Full-length cDNA cloning, molecular characterization and differential expression analysis of peroxiredoxin 6 from Ovis aries. Vet. Immunol. Immunopathol. 2015, 164, 208-219. [CrossRef] [PubMed]

49. Schmitz, G.; Ruebsaamen, K. Metabolism and atherogenic disease association of lysophosphatidylcholine. Atherosclerosis 2010, 208, 10-18. [CrossRef] [PubMed]

50. Graler, M.H.; Goetzl, E.J. Lysophospholipids and their G protein-coupled receptors in inflammation and immunity. Biochim. Biophys. Acta 2002, 1582, 168-174. [CrossRef]

51. Feng, X.L.; Lu, S.Y.; Liu, D.; Li, L.; Wu, X.Z.; Song, J.; Hu, P.; Li, Y.S.; Tang, F.; Li, Z.H.; et al. Direct competitive immunosorbent assay for detection of MEHP in human urine. Chemosphere 2013, 92, 150-155. [CrossRef] [PubMed]

52. NCBI. Available online: http://www.ncbi.nlm.nih.gov (accessed on 30 March 2016).

53. Compute pI/Mw tool. Available online: http://web.expasy.org/compute_pi/ (accessed on 30 March 2016).

54. Motif Scan. Available online: http://hits.isb-sib.ch/cgi-bin/PFSCAN (accessed on 30 March 2016).

55. Lobo de Araujo, A.; Radvanyi, F. Determination of phospholipase $\mathrm{A}_{2}$ activity by a colorimetric assay using a $\mathrm{pH}$ indicator. Toxicon 1987, 25, 1181-1188. [CrossRef] 
56. Ben Bacha, A.; Al-Daihan, S.K.; Mejdoub, H. Purification, characterization and bactericidal activities of phospholipase $\mathrm{A}_{2}$ from the dromedary intestine. Int. J. Biol. Macromol. 2013, 57, 156-164. [CrossRef] [PubMed]

57. Abousalham, A.; Verger, R. Egg yolk lipoproteins as substrates for lipases. Biochim. Biophys. Acta 2000, 1485, 56-62. [CrossRef]

58. Yang, Y.J.; Liu, Z.S.; Lu, S.Y.; Li, C.; Hu, P.; Li, Y.S.; Liu, N.N.; Tang, F.; Xu, Y.M.; Zhang, J.H.; et al. Molecular cloning, expression and characterization of programmed cell death 10 from sheep (Ovis aries). Gene 2015, 558, 65-74. [CrossRef] [PubMed]

59. Zhou, Y.; Zhang, Y.Y.; Shen, Q.F.; Lu, S.Y.; Ren, H.L.; Li, Y.S.; Liu, Z.S.; Pan, F.G.; Meng, X.M.; Zhang, J.H. Development of a novel antibody probe useful for domoic acid detection. Biosens. Bioelectron. 2009, 24, 3159-3163. [CrossRef] [PubMed]

60. Bradford, M.M. A rapid and sensitive method for the quantitation of microgram quantities of protein utilizing the principle of protein-dye binding. Anal. Biochem. 1976, 72, 248-254. [CrossRef]

61. Tang, F.; Ren, H.L.; Xu, Y.M.; Zou, D.Y.; Liu, N.N.; Li, Y.S.; Zhou, Y.; Song, J.; Li, Z.H.; Zhang, Y.Y.; et al. Kinetics and cross-reactivity of the antibody in sheep inoculated with virulent and avirulent Brucella. J. Anim. Vet. Adv. 2012, 11, 1564-1569. [CrossRef]

(C) 2016 by the authors; licensee MDPI, Basel, Switzerland. This article is an open access article distributed under the terms and conditions of the Creative Commons Attribution (CC-BY) license (http://creativecommons.org/licenses/by/4.0/). 